term, or of a folding in a solid condition or any other form of dynamo-metamorphism, and he maintains his original opinion that the serpentine (i.e. the original peridotite) is intrusive in the other rocks.

The paper also deals with some minor points in the geology of the Lizard; the author supplying some additional particulars about the serpentine at Porthkerris and Porthallow, and explaining that he has found the rocks on the south side of Porthoustock Cove to be only a continuation of those which form the crags south of the opening of the Cove, though they are generally less well preserved: namely, a fine-grained gabbro, intrusive in the ordinary Crousa Down gabbro, and "greenstone" dykes cutting both of these.

2. "The "Schistes Lustrés' of Mont Jovet (Savoy)." By J. W. Gregory, D.Se., F.G.S.

The author gives a history of the controversy as to the age of the 'schistes lustrés' of the Western Alps, making special reference to the views of Zaccagna and Bertrand concerning the schists of Mont Jovet. Of these writers, the former maintains that the rocks of the summit of the mountain are old rocks on which the Carboniferous and Triassic strata were deposited unconformably ; while, according to the latter author, the rocks forming the top of the mountain were laid down after those which flank it.

In the present paper the author gives the results of an examination of the rocks of Mont $J_{0 v}$ tecently made by him. He contends that Lory and Zaccagna were correct in identifying the central rocks of Mont Jovet as 'schistes lustrés,' for this conclusion is supported by their lithological characters and the occurrence of basic igneous rocks of the 'pietre-verdi' type associated with them, and is not opposed to their stratigraphical relations. It is further maintained, as the result of the evidence collected by the author, that the schists in question are older than the Trias; for fragments of the schists occur in the Trias, there is a discordance of strike between the two series, masses of dolomite rest unconformably upon the flanks of the schists, and the Trias has escaped metamorphism which the schists have undergone. The probabilities are in favour of the schists occupying the same relation to the Carboniferous as they do to the Trias; while the close approximation of the schists to the former shows that the schists are not the altered representatives of the neighbouring Carboniferous beds, and it is therefore concluded that 'the 'schistes lustrés' are pre-Carboniferous, but evidence by which finally to assign them to any exact horizon before this date is still wanting.

\title{
CORIFSPONDEINOE.
}

\section{ON THE USE OF THE TERM BOLDERIEN.}

Sin,-Will you allow me a few words on the term Bolderien as applied in the abstract of the interesting paper of Mr. G. F. Dollfus (GEol. MaG., October 1895, p. 474) on the seas during Upper 
Tertiary times in Western Europe. This name was originated by Dumont for the white sands, without fossils, which appear in the Bolderberg, near Hassalt. We can observe these sands, in places, on the banks of the Rhine, where they contain fossils, and are classed as Upper Oligocene. The Miocene of Belgium is the Crag noir d'Anvers, part of the Diestien of Dumont, the Anversien of Cogels and Van Ertborn.

Lately, M. E. Van den Broeck has endeavoured to demonstrate on the evidence of fossils found in the upper beds of the Bolderien at Waenrode, that the Boldérien and Anversien are synonymous, and, consequently, that the term Anversien, being newer, must be cancelled. This view, it appears, was adopted by $M$. Dollfus; but I still maintain that this correlation is by no means well founded, and agree with Cogels and others that our ancient Boldérien is Oligocene.

UnIVERSITÉ DE LIÉGE; October $29 t h, 1895$.

\section{Dewalque.}

\title{
OBITUARY.
}

\section{DR. ERNST VON REBEUR-PASCHWITZ.}

\author{
Borv AUgust 9Th, 1861.
}

Died OCTOBER 1st, 1895.

Dr. Ernst von Rebeur-Paschwitz was born on August 9th, 1861, at Frankfurt a. Oden. In consequence of his father's movements as a Government officer, Von Rebeur's school was often changed, but wherever he went his knowledge of mathematics made him in these studies facile princeps. He obtained his doctorate at Berlin, where he became an assistant at the Observatory. At Karlsruhe, where he was 'Erster Assistant,' he commenced, in 1884, to interest himself in Zöllner's pendulum. It was about this time that his health first caused anxiety to his friends. Although he visited Switzerland, Italy, Teneriffe, and other places, returning to his home in apparently good health, it was soon recognized that his recoveries were only temporary. At Halle, where he was Privat Docent, the condition of his throat and chest precluded him from giving lectures. From 1891 until his death, on October 1st, 1895, he was more or less confined to a bed or sofa, often suffering excruciating pain, and never left his room excepting during the summer.

It was during this period of physical incapacity that Von Rebeur produced his most remarkable work, and became the pioneer of a new seismology. Commencing with the endeavour to measure lunar gravitation, he discovered the diurnal wave, that earthquakes could be recorded at stations distant more than a quarter of the earth's circumference from their origin, came in contact with the ubiquitous tremors, and observed many other phenomena connected with the movements of our so-called terra firma. 'These discoveries attracted the attention of other observers, and horizontal pendulums were established at several of the more important observatories in Germany and Russia. 